\title{
Las deficiencias formales y pragmáticas de los medios de control constitucional en México
}

\author{
The Formal and Pragmatic Deficiencies of the Means \\ of Constitutional Control in Mexico
}

As deficiências formais e pragmáticas dos meios de controle constitucional no México

\section{Erick Francisco Tapia Hernández ${ }^{1}$}

\begin{abstract}
Recibido: 8 de julio de 2020 Aprobado: 31 de agosto de 2020 Publicado: 12 de enero de 2021

Cómo citar este artículo: Erick Francisco Tapia Hernández. Las deficiencias formales y pragmáticas de los medios de control constitucional en México. DIXI, vol. 23, n. 1, enero-junio 2021, 1-35.

DOI: https://doi.org/10.16925/2357-5891.2021.01.09
\end{abstract}

Artículo de reflexión. https://doi.org/10.16925/2357-5891.2021.01.09

1 Doctor en Derecho con mención honorifica. Maestro en Derecho con mención honorifica. Especialidad en Derecho Constitucional y Administrativo. Licenciado en Derecho. Todos los anteriores obtenidos en la Universidad Nacional Autónoma de México (Unam). Posdoctorado adscrito al posgrado en Ciencias Sociales en la Universidad Autónoma Metropolitana sede Xochimilco.

Correo electrónico: dr.ericktapiah@gmail.com; erick.tapia@uaq.mx; etapia@comunidad.unam.mx 


\section{Resumen}

Propósito: en México, existen tres medios de control constitucional; sin embargo, han sido superados en cuanto a su alcance y protección debido a que hay actos de autoridad que no están regulados para su control o están prohibidos expresamente por la ley.

Metodología: en el presente estudio, analizaremos el alcance de los medios de control constitucional, los cuales son: las controversias constitucionales, las acciones de inconstitucionalidad y el juicio de amparo.

Hallazgos: advertiremos que es un tema complejo de plantear en México tanto en lo político como en lo jurídico, agudizado por el intento de adaptar figuras algo obsoletas o por lo menos insuficientes a la exigencia de un nuevo sistema de justicia constitucional que todo Estado constitucional debería tener. Ello ha contribuido a que en México la justicia tenga una percepción de incertidumbre tanto en la ley como en la práctica por todos los operadores de justicia involucrados.

Conclusiones: en el desarrollo del presente estudio, hemos advertido que el sistema de justicia para la defensa de derechos humanos en México es deficiente, en particular en cuanto a los medios de control constitucional tanto en estructura como en hipótesis normativas ausentes y otras incluso prohibidas.

Palabras clave: acciones de inconstitucionalidad, control constitucional, controversias constitucionales, juicio de amparo.

\section{Abstract}

Purpose: In Mexico, there are three means of constitutional control; however, they have been surpassed in terms of their scope and protection due to the fact that there are acts of authority that are not regulated for their control or are expressly prohibited by law.

Methodology: In this study, we will analyze the scope of the means of constitutional control, which are: constitutional controversies, actions of unconstitutionality and the amparo trial.

Findings: We will notice that this is a complex issue to be raised in Mexico, both politically and legally, aggravated by the attempt to adapt somewhat obsolete or at least insufficient figures to the demands of a new system of constitutional justice that every constitutional State should have. This has contributed to the perception of uncertainty in the justice system in Mexico, both in law and in practice, by all the justice operators involved.

Conclusions: In the development of this study, we have warned that the justice system for the defense of human rights in Mexico is deficient, particularly in terms of the means of constitutional control both in structure and in normative hypotheses that are absent and others that are even prohibited.

Keywords: Unconstitutionality actions, constitutional control, constitutional controversies, amparo trial.

\section{Resumo}

Objetivo: no México, existem três meios de controle constitucional; entretanto, eles foram superados em termos de seu escopo e proteção devido ao fato de que existem atos de autoridade que não são regulamentados para seu controle ou são expressamente proibidos por lei.

Metodologia: neste estudo, analisaremos o escopo dos meios de controle constitucional, que são: controvérsias constitucionais, ações de inconstitucionalidade e o julgamento amparo.

Resultados: notaremos que é uma questão complexa a ser levantada no México tanto política quanto juridicamente, agravada pela tentativa de adaptar números algo obsoletos ou pelo menos insuficientes à exigência de um novo sistema de justiça constitucional que todo Estado constitucional deveria ter. Isto contribuiu para o fato de que a justiça no México tem uma percepção de incerteza tanto na lei quanto na prática por parte de todos os operadores de justiça envolvidos. 
Conclusões: no desenvolvimento deste estudo, advertimos que o sistema judicial para a defesa dos direitos humanos no México é deficiente, particularmente em termos de meios de controle constitucional, tanto na estrutura como nas hipóteses normativas ausentes e outras até mesmo proibidas.

Palavras-chave: ações de inconstitucionalidade, controle constitucional, controvérsias constitucionais, julgamento amparo

\section{INTRODUCCIÓN}

En México, existe un poder judicial en cada una de las 32 entidades federativas y uno para la Federación'; cada entidad federativa cuenta con un tribunal superior de justicia que se aboca, en su mayoría, a casos que versan sobre problemas de legalidad, toda vez que no se tiene instituido un sistema difuso en México, pese a lo ordenado en la resolución del expediente varios 912/2010², dictada por la Corte Interamericana de Derechos Humanos. Respecto a la Federación, para el tema que nos ocupa, en orden ascendente tenemos a los Juzgados de Distrito, los Tribunales Colegiados de Circuito y la Suprema Corte de Justicia de la Nación que funciona en Pleno y en Salas. Advierta el lector que no tenemos Tribunal Constitucional, sino que a la misma Suprema Corte que pertenece al Poder Judicial de la Federación se le han conferido competencias de órgano de control político mediante dos medios de control de la constitucionalidad que tienen forzosamente por ley que atender en Pleno y que son: las acciones de inconstitucionalidad y las controversias constitucionales.

Cabe precisar que el juicio de amparo se sustancia en el poder judicial federal, por lo cual es importante señalar que la mayoría de asuntos ${ }^{3}$ con origen en juzgados locales y salas de los Tribunales Superiores de Justicia de las entidades federativas en los que se aluden violaciones a derechos humanos también son resueltos por el

1 México es una Federación. Señala el artículo 40: "Es voluntad del pueblo mexicano constituirse en una República representativa, democrática, laica y federal, compuesta por Estados libres y soberanos en todo lo concerniente a su régimen interior, y por la Ciudad de México, unidos en una federación establecida según los principios de esta ley fundamental". Constitución Política de los Estados Unidos Mexicanos, Art. 40, 5 de febrero de 1917 (México), Disponible en: https://www.juridicas.unam.mx/legislacion/ ordenamiento/constitucion-politica-de-los-estados-unidos-mexicanos

2 En el punto 22, punto sexto, refieren respecto a las obligaciones concretas del poder judicial en México, en el caso Rosendo Radilla: "A) Los jueces deberán llevar a cabo un control de convencionalidad ex officio en un modelo de control difuso de constitucionalidad". Disponible en: https://www.scjn.gob.mx/sites/default/files/estrado_electronico_notificaciones/documento/2018-08/SENTENCIA-EXP-VARIOS-912-2010PLENO.pdf

3 Recordemos que hay entidades con justicia constitucional establecida que tienen que ver con control constitucional local más que por protección de derechos humanos, por ejemplo, la Constitución de la Ciudad de México, Artículo 36 B (5 de febrero de 2017). Disponible en: https://www.scjn.gob.mx/sites/default/files/justicia_constitucional_local/documento/2020-01/118922.pdf 
primero citado, a pesar de que la justicia local con base en los artículos $1^{4}$ y 128 de la Constitución ${ }^{5}$, así como en la resolución citada de la Corte Interamericana, tendría el deber y la facultad de aplicar el control constitucional difuso directamente, lo cual en la práctica no sucede, por lo que los ciudadanos acuden al juicio de amparo.

Si bien en el presente estudio no corresponde propiamente analizar si en México se tiene un control concentrado, control difuso por órgano de control político o jurisdiccional ${ }^{6}$, en cada caso se hará referencia directa al medio de control, su procedencia y su particularidad. Al respecto, es preciso mencionar que en México existe un sistema mixto ${ }^{7}$ y que los medios de control constitucional son aquellos medios establecidos por el Estado con el fin de revisar (y en dado caso, anular) cualquier acto de autoridad que sea contrario a la Constitución y, ahora en México, a los tratados internacionales de acuerdo con los artículos 1 y 133 constitucionales. En ese tenor, la Suprema Corte de Justicia de la Nación en México ofrece la siguiente definición de los medios de control constitucional: "Son los instrumentos a través de los cuales se busca mantener o defender el orden establecido por la Constitución Política de los Estados Unidos Mexicanos", el cual tiene por objeto "verificar que no existan normas que contradigan al texto fundamental, ya sea que se efectúe el control en una etapa previa a la entrada de la propuesta normativa al ordenamiento jurídico (control a priori) o bien cuando una norma aplicada a un caso concreto provoca la vulneración de la Constitución (control a posteriori)"9.

4 Artículo 1: "Todas las autoridades, en el ámbito de sus competencias, tienen la obligación de promover, respetar, proteger y garantizar los derechos humanos de conformidad con los principios de universalidad, interdependencia, indivisibilidad y progresividad. En consecuencia, el Estado deberá prevenir, investigar, sancionar y reparar las violaciones a los derechos humanos, en los términos que establezca la ley [...]".

5 Artículo 128 constitucional: "Todo funcionario público, sin excepción alguna, antes de tomar posesión de su encargo, prestará la protesta de guardar la Constitución y las leyes que de ella emanen".

6 Para ver cómo se encuentra establecido el control constitucional en México, respecto a su estructura y funciones, véase: Erick Francisco Tapia Hernández. La necesidad de un Órgano de Control Político independiente del Poder Judicial de la Federación. VEREDAS, REVISTA DEL PENSAMIENTO SOCIOLóGICo 37. Julio-diciembre 2018. Disponible en: http://www.casadelibrosabiertos.uam.mx/contenido/contenido/Libroelectronico/ veredas-37-web.pdf

7 Miguel Covian Andrade. EL CONTROL DE LA CONSTITUCIONALIDAD. FUNDAMENTOS TEÓRICOS Y SISTEMAS DE CONTROL. Instituto de Investigaciones legislativas del Senado de la República. (2013). Disponible en: https://archivos.juridicas.unam.mx/www/bjv/ libros/7/3180/9.pdf

8 ¿Qué hace la Suprema Corte de Justicia de la Nación? Disponible en: https://www.scjn. gob.mx/conoce-la-corte/que-hace-la-scjn

9 Enrique Díaz Bravo. ANÁLISIS Y REFLEXIONES SOBRE EL CONTROL DE CONSTITUCIONALIDAD DE LAS LEYES. REVISTA OPINIÓN JURÍDICA 30. Julio-diciembre 2016. Pág. 25-46. doi: https://doi.org/10.22395/ojum.v15n30a1 
Por lo que hace a los medios de control constitucional, en México de 1917 a 1994 se promovieron 54 controversias constitucionales, de las cuales catorce fueron entre la Federación y una entidad federativa, veintidós fueron entre poderes de una misma entidad federativa, una fue entre diversas entidades federativas, doce fueron entre municipios y entidades federativas y una fue entre un municipio y una entidad federativa ${ }^{10}$. Lo anterior evidencia que era una figura en desuso al ser ejercida únicamente 54 veces en casi ochenta años. Fue hasta diciembre de 1994, momento en que el presidente de la República entró al poder, que se ampliaron las hipótesis de la controversia constitucional y se implementaron como novedad las acciones de inconstitucionalidad en el artículo 105 constitucional.

Si bien es cierto que México no cuenta con un tribunal constitucional en sentido estricto, a la Suprema Corte de Justicia de la Nación se le asignan funciones de tribunal constitucional en 1994, a pesar de que pertenece al Poder Judicial de la Federación ${ }^{11}$ y que operó prácticamente como tribunal de casación. De hecho, sigue ejerciendo ese control constitucional de casación respecto a la legalidad mediante amparo en las dos Salas que la conforman, a saber: una en materia civil y penal y la otra en materia administrativa y laboral; aunado a la función del Pleno que es ejercer el control constitucional concentrado propiamente dicho, como se analizará más adelante. El presidente en turno optó, en 1994, que el Pleno sería el único competente para resolver estos medios de control y que los demás poderes estatales serían los facultados para promoverlos; en ese sentido, se excluyó la facultad a los ciudadanos desde un inicio para impugnar mediante estos medios de control.

Este trabajo se aboca en mayor medida al juicio de amparo, debido a que se ha sobreestimado como único medio de protección de garantías y derechos humanos en México y a que se le ha presentado como solución a casi todos los conflictos que pudieran suscitarse, más aún con las reformas constitucionales del 10 de junio de 2011, lo cual implicó que en México se consideraran los derechos humanos de los tratados internacionales ${ }^{12}$ de los que el Estado sea parte. En ese sentido, se amplió

10 Fabiola Martínez Ramírez. LAS controversias constitucionales COMO MEDIO DE CONTRol constitucional. Editorial Universidad Nacional Autónoma de México. (s. f.). Disponible en: https://archivos.juridicas.unam.mx/www/bjv/libros/6/2553/24.pdf

11 Artículo 49 constitucional: "El Supremo Poder de la Federación se divide para su ejercicio en Legislativo, Ejecutivo y Judicial [...]".

12 Artículo 1 constitucional: "En los Estados Unidos Mexicanos todas las personas gozarán de los derechos humanos reconocidos en esta Constitución y en los tratados internacionales de los que el Estado Mexicano sea parte, así como de las garantías para su protección, cuyo ejercicio no podrá restringirse ni suspenderse, salvo en los casos y bajo las condiciones que esta Constitución establece [...]". 
el catálogo de protección de los derechos humanos ${ }^{13}$, y la otra reforma referente a la Ley de Amparo en el año 2013, que deviene de la reforma del 6 de junio de 2011; ley que también suscitó la controversia acerca de si su articulado tuviese la posibilidad de sujetarse a control de la constitucionalidad ${ }^{14}$.

En atención a que el control constitucional en materia de amparo está íntimamente relacionado con el control del poder en relaciones de supra a subordinación, dejaremos de lado aquellos asuntos que de origen versan sobre problemas de legalidad, en virtud de que dichos asuntos por lo regular concluyen en los Tribunales Colegiados de Circuito y no llegan a las Salas de la Suprema Corte de Justicia de la Nación, por lo que no tienen nada que ver con lo constitucional (verbigracia, una compraventa o un pagaré), toda vez que si en el juicio de origen el juez o los magistrados realizan una valoración de pruebas de forma contraria a lo que estipula la ley, procederá el amparo por violaciones a la Constitución. Sin embargo, ordinariamente el asunto no llegará a la Suprema Corte debido a que la instancia máxima contemplada en este tipo de asuntos es el Tribunal Colegiado de Circuito ${ }^{15}$.

En relación con el juicio de amparo, cabe precisar que es un medio de control constitucional que procede contra actos de autoridad y normas generales, con la particularidad de que es el único que pueden promover los ciudadanos.

Dentro de la importancia que reviste el tema fue que se consideró, en la reforma del 6 de junio de 2011, que los medios de control constitucional se substanciarán y resolverán de manera prioritaria cuando alguna de las Cámaras del Congreso o el Ejecutivo Federal justifique la urgencia atendiendo al interés social o al orden público ${ }^{16}$.

En México, la discusión sobre la competencia del Poder Judicial debería ser añeja puesto que, como señala Vigo, el mérito de la creación del Tribunal Constitucional desde 1920 es de Kelsen ${ }^{17}$. A decir por la fecha, parecería que el tema en México

13 Lo anterior implicó un problema para México que ha realizado jurisprudencias con el fin de frenar la procedencia, en: Erick Francisco Tapia Hernández y Alba Aurora Olvera Bustamante. La posición jurídica del Estado mexicano ante la jerarquía normativa de los tratados internacionales y la jurisprudencia de la Corte Interamericana de Derechos Humanos. Comisión Interamericana de Derechos Humanos (CIDH). 60 AÑOS DE LA COMISIÓN INTERAMERICANA DE DERECHOS HUMANOS. CIDH. (2020).

14 Margarita Beatriz Luna Ramos. Control constitucional sobre la Ley de Amparo. Coords. David Cienfuegos Salgado y Jesús Boanerges Guinto López. EL DERECHO MEXICANO CONTEMPORÁNEO RETOS Y DILEMAS. Editorial Universidad Autónoma de Chiapas. (2012). Pág. 359.

15 La creación de acuerdos para delegar competencia originaria de la Corte a los Tribunales Colegiados de Circuito también surge en la reforma del año 1994. Disponible en: https://archivos.juridicas.unam.mx/www/legislacion/federal/reformas/rc133.pdf

16 Artículo 94 constitucional.

17 Rodolfo Vigo. LA INTERPRETACIÓN (ARGUMENTACIÓN) JURÍDICA EN EL ESTADO DE DERECHO CONSTITUCIONAL. Editorial Tirant lo Blanch. (2017). Pág. 70. 
debería estar agotado. Sin embargo, el primer acercamiento real lo tuvimos fue en la reforma de 1994 y a partir de la diversa de 2011; por ende, es inaplazable discutir seriamente el tema desde varias aristas. En febrero de 2020, se presentó una reforma al Poder Judicial de la Federación por parte del presidente actual de la Suprema Corte de Justicia de la Nación, pero su estudio quedó suspendido por la pandemia que afronta el país ${ }^{18}$. La necesidad de establecer una organización fehaciente es inminente, toda vez que en los países que se precien de ser democráticos tiene que haber una institución final que realice la interpretación judicial; esto se suma a los problemas acerca de la competencia de control del Tribunal Constitucional, así lo señala Alexy refiriéndose a Alemania pero aplicable también a México: "En el centro del prolongado y arduo debate acerca de la jurisdicción del Tribunal Constitucional, se encuentra la cuestión de cómo equilibrar las competencias del Tribunal Constitucional y las del legislador"19.

Buscar este equilibrio entre poderes se complica cuando se tienen medios de control constitucional insuficientes y se agudiza con las diversas técnicas de interpretación constitucional que hay, ya que como señala Guastinni, "para la Constitución deben emplearse reglas o técnicas de interpretación peculiares, diversas de las que se emplean para otros documentos normativos"20, al igual que a partir de la reforma en México de derechos humanos es una exigencia conocerlas, ya que son parte de los pilares del cambio del Estado Legal al Estado Constitucional, pues como señala Zagrebelsky al respecto: "[...] las normas constitucionales sobre derechos y sobre la justicia son prevalentemente principios"21. Implementación que se debe atender de manera seria e inmediata.

Lo anterior se suma a que hay materias que nos presentan nuevos retos, como la bioética, o supuestos que se fundan en derechos humanos que antes no habíamos visto y presentan ciertas particularidades. Al respecto señala Atienza: "Además de casos simples hay también casos difíciles (de los que se ocupa especialmente la teoría de la argumentación jurídica)"22. De ahí lo apremiante de atender el tema, necesidad que abordaremos en el presente estudio.

18 Proyecto de reformas con y para el Poder Judicial de la Federación, febrero 2020. Disponible en: https://www.scjn.gob.mx/sites/default/files/carrusel_transarencia/documento/2020-02/Reforma-Judicial-PJF.pdf

19 Robert Alexy. TEOría de Los DeREchos fundamentales. Centro de Estudios Constitucionales. (1993). Pág. 526.

20 Riccardo Guastini. ESTUdIOS SOBRE LA INTERPRETACIÓN CONSTITUCIONAL. 7. a edición. Editorial Porrúa. (2006). Pág. 120.

21 Gustavo Zagrebelsky. EL DERECHO DúCTIL. 5. a edición. Editorial Trotta. (2003). Pág. 110.

22 Manuel Atienza. LAS RAZONES DEL DERECHO. TEORÍAS DE LA ARGUMENTACIÓN JURÍDICA. Editorial Universidad Nacional Autónoma de México. (2003). Pág. 26. 
Un interrogante recurrente en el tema que se aborda, en lo particular, radica en los límites de los derechos humanos en cuanto a la interpretación, toda vez que, como señala Cappelletti, "la interpretación 'pura' no existe; toda la interpretación comporta un elemento de creatividad"23. Situación que implica sustancialmente el cambio de un Estado Legal o Estado de Derecho a uno Constitucional. Al respecto, señala Zagrebelsky: "[...] se advierte que, más que de una continuación, se trata de una profunda transformación que incluso afecta necesariamente a la concepción del derecho"24. Lo anterior no es baladí, puesto que a partir de 2011 se obliga a los operadores jurídicos a aplicar el neoconstitucionalismo, tópico que va de la mano con la organización y la competencia de los jueces constitucionales.

Al hablar de control constitucional en México, no debe olvidarse que está íntimamente relacionado con la supremacía constitucional y que, derivado de la reforma constitucional de 2011, existe la misma jerarquía entre esta y los tratados internacionales suscritos por nuestro país en materia de derechos humanos, siempre y cuando no contengan una limitación expresa en la Constitución ${ }^{25}$.

Por lo que hace a las determinaciones de constitucionalidad sobre la materia de consultas populares ${ }^{26}$, la Suprema Corte lo cita como medio de control constitucional en su página oficial, indicando que la ley está pendiente ${ }^{27}$; sin embargo, dicha ley fue publicada en marzo de $2014^{28}$. Respecto al procedimiento, la ley señala que cuando sea el presidente ${ }^{29}$ quien solicite la consulta, o por lo menos lo haga el $33 \%$ de los integrantes de cualquiera de las Cámaras del Congreso $^{30}$ o los ciudadanos ${ }^{31}$, se

23 Mauro Cappelletti. LA JUSTICIA CONSTITUCIONAL (ESTUdios DE DERECHO COMPARADO). Editorial Universidad Nacional Autónoma de México. (1987). Pág. 201.

24 Gustavo Zagrebelsky, supra, nota 22, pág. 34.

25 Contradicción de Tesis 293/2011, Rubro 1: "Derechos humanos contenidos en la Constitución y en los tratados internacionales. Constituyen el parámetro de control de regularidad constitucional, pero cuando en la Constitución haya una restricción expresa al ejercicio de aquellos, se debe estar a lo que establece el texto constitucional". Gaceta del Semanario Judicial de la Federación, Décima Época, Libro 5, Tomo I, abril de 2014, página 96.

26 Establecida en el artículo 35 constitucional en los derechos del ciudadano: "VIII. Votar en las consultas populares sobre temas de trascendencia nacional, las que se sujetarán a lo siguiente [...]".

27 ¿Qué son las determinaciones de constitucionalidad sobre la materia de consultas populares? Disponible en: https://www.scjn.gob.mx/conoce-la-corte/que-hace-la-scjn

28 Publicada en el Diario Oficial de la Federación, 14 de marzo de 2014, decreto por el que se expide la Ley Federal de Consulta Popular. Disponible en: http://www.dof.gob.mx/ nota_detalle.php?codigo $=5337123 \&$ fecha $=14 / 03 / 2014$

29 Artículo 27, Ley Federal de Consulta Popular.

30 Ibid.

31 Ibid. Artículo 28. 
enviará a la Suprema Corte de Justicia de la Nación para que resuelva sobre la constitucionalidad o inconstitucionalidad de la materia de la consulta. En la primera y tercera hipótesis revisará además que la pregunta que derive directamente de la materia de la consulta no sea tendenciosa o contenga juicios de valor; emplee lenguaje neutro, sencillo, comprensible, y produzca una respuesta categórica en sentido positivo o negativo; así mismo se indica que sus resoluciones serán definitivas e inatacables ${ }^{32}$.

No obstante lo anterior, no se puede asumir como medio de control constitucional a la consulta en virtud de que el papel de la Suprema Corte es consultivo y no tiene por efecto anular un acto de autoridad; solo es parte de un requisito en un procedimiento, no es un acto de imperio materializado o inminente que la Suprema Corte deba controlar. Por el contrario, es una ley con deficiencias en cuanto a su alcance, ya que no permite que puedan ser materia de la consulta popular los temas electorales, los ingresos y los gastos del Estado ${ }^{33}$.

Aunado a lo anterior, encontramos un obstáculo para la procedencia de la consulta popular derivado de una facultad discrecional, ya que señala la ley que solo serán objeto de la consulta los temas de trascendencia nacional, la cual será calificada por la mayoría de los legisladores presentes en cada Cámara, con excepción de la consulta propuesta por los ciudadanos, en cuyo caso lo resolverá la Suprema Corte de Justicia de la Nación. El resultado de la consulta será vinculante para los poderes Ejecutivo y Legislativo federales, así como para las autoridades competentes, pero únicamente cuando la participación total sea del 40 \% de los ciudadanos inscritos en la lista nominal de electores ${ }^{34}$.

En ese sentido, la consulta popular no puede considerarse un medio de control constitucional en sentido estricto, ya que se trata de un control previo de constitucionalidad con tintes políticos, toda vez que no fue creado como un medio de control constitucional.

Consideramos que, más bien, se trata de un medio preventivo de defensa de la Constitución, como señalan Valencia Carmona y Fix Zamudio: "[...] podemos afirmar que la defensa de la Constitución está integrada por todos aquellos instrumentos jurídicos y procesales que se han establecido tanto para conservar la normativa constitucional como para prevenir su violación, reprimir su desconocimiento y, lo que es más importante, lograr el desarrollo y la evolución de las propias disposiciones

\footnotetext{
32 Ibid. Artículo 29.

33 Ibid. Artículo 11, Fracción III y IV.

34 Ibid. Artículo 5.
} 
constitucionales" ${ }^{\prime 35}$. Se encuentra en los medios de defensa de la Constitución en la categoría de protección a la Constitución ${ }^{36}$. Lo anterior, toda vez que el control de la constitucionalidad se ejerce sobre aquellos actos inminentes que gozan de imperio, como por ejemplo una ley que se encuentra en la categoría de justicia constitucional.

Para el propósito del presente trabajo, se utilizarán los métodos deductivo, inductivo, exegético, analógico, dialéctico y comparativo para dilucidar el modelo de justicia previo y posterior a la reforma de 2011 y a las implicaciones en la transición de un Estado Legal a un Estado Constitucional.

\section{CONTROVERSIAS CONSTITUCIONALES}

Al ser México una federación con tres niveles de gobierno: municipio, entidades federativas y Federación, se suscitan problemas entre dichos niveles por invasión de competencias o por vulneración a la Constitución. Por tal razón, fueron creadas las controversias constitucionales como medio de control constitucional cuyo objeto es dirimir esos asuntos, hacer notar que todas las autoridades del poder ejecutivo y legislativo son elegidos por voto libre y secreto, y por tanto, en sus decisiones ejercen la democracia indirecta, lo que obliga a que el medio de control que pueda afectarlos adquiera una relevancia máxima desde la ciencia jurídica y la teoría política. Las controversias constitucionales son definidas como:

[...] procesos mediante los cuales se resuelven los conflictos que surjan entre dos de los Poderes Federales — Legislativo y Ejecutivo-, los Poderes de los Estados — Legislativo, Ejecutivo y Judicial—, los Órganos de Gobierno del Distrito Federal —Legislativo, Ejecutivo y Judicial_, o bien entre los órdenes de gobierno — federal, estatal, municipal o del Distrito Federal-, por invasión de competencias o bien por cualquier tipo de violación a la Constitución Federal, por parte de los órganos señalados. Corresponde exclusivamente a la SCJN resolver estos procesos. ${ }^{37}$

35 Héctor Fix Zamudio y Carmona Valencia. DERECHO CONSTITUCIONAL, MEXICANO Y COM-

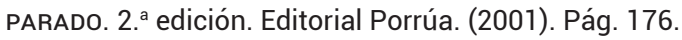

36 Ibid. Pág. 177 y ss.

37 ¿Qué hace la Suprema Corte de Justicia de la Nación? Disponible en: https://www.scjn. gob.mx/conoce-la-corte/que-hace-la-scjn 
Respecto a la naturaleza de la controversia constitucional de acuerdo con la Suprema Corte de Justicia de la Nación, fue instaurada para garantizar el principio de división de poderes. Se plantea una invasión de las esferas competenciales establecidas en la Constitución, y solo puede ser proyectada por la Federación, las Entidades Federativas y los Municipios. La parte promovente plantea la existencia de un agravio en su perjuicio y se realiza todo un proceso, desde la demanda hasta la sentencia. En cuanto a las normas generales, no pueden impugnarse normas en materia electoral. Así mismo, por lo que hace a los actos cuya inconstitucionalidad puede plantearse, pueden impugnarse normas generales y actos cuyos efectos en la sentencia, tratándose de normas generales, declararán la invalidez de la norma con efectos generales, siempre que se trate de disposiciones de las entidades federativas o de los Municipios impugnados por la Federación, de los Municipios impugnados por las entidades federativas ${ }^{38}$ o bien en conflictos de órganos de atribución, y siempre que la sentencia haya sido aprobada por una mayoría de por lo menos ocho votos de los ministros de la Suprema Corte ${ }^{39}$.

La finalidad de las controversias constitucionales es "fortalecer el federalismo y garantizar la supremacía de la Constitución. Cabe señalar que el Poder Judicial de la Federación no está facultado para iniciarlos como parte. Así mismo, no es posible iniciar controversias constitucionales en contra del Poder Judicial de la Federación ni de los órganos que lo integran"40. Lo anterior, como se advierte, es una omisión, ya que cualquier persona u órgano debería estar legitimado para iniciar una controversia, toda vez que en un Estado de Derecho es importante que no se violente la Constitución, independientemente de sufrir un perjuicio o no, pues la vulneración de esta es un perjuicio en sí. Por ello, sería conveniente establecer un órgano externo al poder judicial, y este último debería ser el único competente para resolver los medios de control constitucional, ya que actualmente se pueden realizar actos por parte del Poder Judicial Federal que vulneren su competencia o la Constitución y crea incertidumbre jurídica sobre qué medio de defensa se utilizaría o sobre si un acto se puede

38 Estos dos últimos supuestos no se encuentran contemplados en la Fracción I del artículo 105 constitucional, referente a las controversias constitucionales, lo que indica que materialmente se piensa más en un centralismo que en federalismo y se piensa más en los actores que en la naturaleza del acto impugnado.

39 Tesis Jurisprudencia (Constitucional) P./J. 71/2000, Rubro: “Controversias constitucionales y acciones de inconstitucionalidad. Diferencias entre ambos medios de control constitucional". Semanario Judicial de la Federación y su Gaceta, Novena Época, 191381, Pleno, Tomo XII, agosto de 2000, Pág. 965.

40 Sistema de Información Legislativa, Secretaría de Gobernación. Disponible en: http:// sil.gobernacion.gob.mx/Glosario/definicionpop.php?ID=57 
convertir en medio de presión para ese poder constituido ${ }^{41}$. Contrario a lo enunciado, la Suprema Corte señala que:

[...] en la promoción de la controversia constitucional, el promovente plantea la existencia de un agravio en su perjuicio; sin embargo, dicho agravio debe entenderse como un interés legítimo para acudir a esta vía el cual, a su vez, se traduce en una afectación que resienten en su esfera de atribuciones las entidades, poderes u órganos a que se refiere la fracción I del artículo 105 de la Constitución Política de los Estados Unidos Mexicanos. ${ }^{42}$

Lo más relevante es que aparte de los efectos generales supeditados a la votación de números de ministros, a la que haremos referencia en líneas posteriores, el legislador mexicano confundió y agregó dos supuestos jurídicos que son de naturaleza distinta en la misma figura, como son: los conflictos entre órganos y las controversias constitucionales, ya que el primero versa sobre un problema que existe entre dos órganos constituidos, por ejemplo, de competencias; y el segundo versa, por ejemplo, cuando se notifica a la Suprema Corte que alguien hizo una ley o acto que viola la Constitución, diferencia que se advierte claramente, por ejemplo, en España ${ }^{43}$.

\section{ACCIÓN DE INCONSTITUCIONALIDAD}

Es un medio de control constitucional que se sustancia en la Suprema Corte, a través del cual "se denuncia la posible contradicción entre la Constitución y alguna norma o disposición de carácter general de menor jerarquía -ley, tratado internacional,

41 Recientemente, se realizó en México la Ley de Remuneraciones de los Servidores Públicos que afecta también a los integrantes del Poder Judicial, y la forma en que tuvo competencia para conocer fue porque la Comisión Nacional de los Derechos Humanos interpuso una acción de inconstitucionalidad, ya que el Poder Judicial de la Federación no está legitimado para promoverlas. Véase: Diario Oficial de la Federación del 19 de julio de 2019, sentencia dictada por el Tribunal Pleno de la Suprema Corte de Justicia de la Nación en la Acción de Inconstitucionalidad 105/2018 y su acumulada 108/2018. Disponible en: https://dof.gob.mx/nota_detalle.php?codigo=5566183\&fecha $=19 / 07 / 2019$

42 Véase: Tesis P./J. 83/2001 de Rubro: "Controversia constitucional. Interés legítimo para promoverla". Semanario Judicial de la Federación y su Gaceta, Novena Época, Tomo XIV, julio de 2001, página 875.

43 Véase: Conflictos entre órganos constitucionales y conflictos de competencia en competencias del Tribunal Constitucional. Disponible en: https://www.tribunalconstitucional.es/es/tribunal/Composicion-Organizacion/competencias/Paginas/default.aspx 
reglamento o decreto-, con el objeto de preservar o mantener la supremacía de la Carta Magna y dejar sin efecto las normas declaradas inconstitucionales"44.

Sin hacer óbice lo anterior, se destaca que el artículo 105, fracción II, de la Constitución señala que este medio sirve para impugnar la contradicción de esta con normas de carácter general, pero no se contemplan los reglamentos y decretos que emite el poder ejecutivo ${ }^{45}$, lo cual reafirmó el pleno de la Suprema Corte de Justicia de la Nación ${ }^{46}$. En las sentencias de acciones de inconstitucionalidad,

[...] la Suprema Corte de Justicia de la Nación corrige los errores que advierta en la cita de los preceptos invocados y suple los conceptos de invalidez planteados en la demanda. Más aún, puede fundar su declaratoria de inconstitucionalidad en la violación de cualquier precepto constitucional, independientemente de que se haya o no invocado en el escrito inicial, en materia electoral solo se referirá a la violación de los preceptos expresamente señalados en el escrito inicial. ${ }^{47}$

En ese sentido, llama la atención que exista la denominada suplencia de la deficiencia de la queja en las acciones de inconstitucionalidad a excepción de la materia electoral, ya que no violar la Constitución o los tratados internacionales es de interés en cualquier Estado de Derecho en cualquier materia; no tendría que hacerse distinción en la materia electoral, dado que la naturaleza de este medio es que la norma no sea contraria a la Constitución ${ }^{48}$.

La Suprema Corte señala que en la acción de inconstitucionalidad se alega una contradicción entre la norma impugnada y una de la propia Constitución; dicha

44 Véase: ¿Qué hace la Suprema Corte de Justicia de la Nación? Disponible en: https:// www.scjn.gob.mx/conoce-la-corte/que-hace-la-scjn

45 Para ver las hipótesis faltantes, véase: Erick Francisco Tapia Hernández. UNA PROPUESTA PARA REGULAR EL CONTROL CONSTITUCIONAL A PRIORI EN MÉXICO (NORMAS DE CARÁCTER GENERAL). Editado por el H. Congreso de la Unión. (2009). Pág. 132 y ss.

46 Véase: Tesis: P./J. 22/99 de Rubro: "Acción de inconstitucionalidad. Solo procede contra normas generales que tengan el carácter de leyes o de tratados internacionales". Semanario Judicial de la Federación y su Gaceta, Novena Época, Tomo IX, abril de 1999, página 257.

47 Suprema Corte de Justicia de la Nación. ¿QUÉ SON LAS ACCIONES DE INCONSTITUCIONALIDAD? 2. a edición. Editorial Suprema Corte de Justicia de la Nación. (2004). Pág. 43. Disponible en: https://www.scjn.gob.mx/sites/default/files/publicaciones_scjn/publicacion/2016-10/51297_pd_0.pdf

48 De igual forma, existe la suplencia de la queja en la controversia constitucional. Valdría la pena materializarla también en cualquier materia en los juicios de amparo. Artículos 39 y 40 de la Ley Reglamentaria de las fracciones I y II del artículo 105 de la Constitución Política de los Estados Unidos Mexicanos. 
contradicción puede ser promovida por el fiscal general de la República, por los partidos políticos o por el 33 \%, cuando menos, de los integrantes del órgano legislativo que haya expedido la norma. Posteriormente, se realiza una solicitud para que el máximo tribunal elabore un análisis abstracto de la constitucionalidad de la norma; acto seguido, se lleva a cabo un procedimiento; pueden combatirse cualquier tipo de normas y una vez resuelta la acción de inconstitucionalidad, la sentencia tendrá efectos generales siempre y cuando esta fuere aprobada por lo menos por ocho ministros ${ }^{49}$.

Puede advertirse la confusión de figuras en nuestro sistema con el caso de la extinción, por decreto presidencial, de la empresa Luz y Fuerza del Centro. Determinación que se terminó impugnando mediante juicio de amparo cuando, de acuerdo con la naturaleza de la acción de inconstitucionalidad, este medio de control constitucional debería haber sido utilizado, de forma colectiva, por los ciudadanos para que hubieran podido acceder a la justicia. No obstante lo anterior, los 44000 agremiados pertenecientes a Luz y Fuerza del Centro acudieron al Congreso de la Unión con el ánimo de que alguna de las Cámaras interpusiera este medio o una controversia constitucional defendiendo los derechos que aludían, pero al ser la mayoría de los miembros de las Cámaras del mismo partido que el del presidente de la República, la minoría no alcanzaba el porcentaje requerido y por tanto no se pudo impugnar por este tipo de medios. El medio, en dado caso, debió ser por controversia constitucional por no contemplarse los decretos presidenciales como supuesto de impugnación en las acciones de inconstitucionalidad, lo cual es una incoherencia a todas luces, porque el medio que se comenta precisamente es o debería ser para impugnar normas generales.

En México, no existe el control constitucional a priori o previo ${ }^{50}$ respecto al órgano encargado de control constitucional. Existe una revisión política llevada a cabo para tratados internacionales por:

[...] la Presidencia de la República, a través de la Secretaría de Relaciones Exteriores y la Consejería Jurídica del Ejecutivo Federal, que son las instancias encargadas, entre otras funciones, de examinar la constitucionalidad de los tratados internacionales que suscribe el Ejecutivo; y por otro está el propio Senado de la República que realiza un segundo análisis de constitucionalidad a través de los comisiones respectivas antes de

49 Tesis Jurisprudencia (Constitucional) P./J. 71/2000, Rubro: "Controversias constitucionales y acciones de inconstitucionalidad. Diferencias entre ambos medios de control constitucional". Semanario Judicial de la Federación y su Gaceta, Novena Época, 191381, Pleno, Tomo XII, agosto de 2000, página 965.

50 Erick Francisco Tapia Hernández, supra, nota 46. 
ser aprobados por el Pleno de ese órgano. Esto explicaría por qué, en la práctica, existan pocas probabilidades de que una minoría de $33 \%$ de senadores impugne la constitucionalidad de un tratado mediante una acción de inconstitucionalidad. ${ }^{51}$

Advertimos en lo anterior que los controles otra vez quedan anulados por la política; toda vez que tanto el secretario de Relaciones Exteriores como el consejero jurídico del Ejecutivo Federal son empleados del Presidente de la República. Así que, de buena fe y siguiendo lo ordenado por el artículo 128 constitucional, deberían revisar y en dado caso asesorar al presidente indicándole que el tratado no se puede firmar, pero si él insiste, nada puede hacerse; de igual forma si el partido político del presidente tiene mayoría en la Cámara de Senadores, será inminente la aprobación.

Otro de los grandes problemas es que requiere el 33 \% de la Cámara que emitió el acto, y algunos ordenamientos legales para su creación piden mayoría simple para la aprobación, así que puede darse el caso en que se esté pidiendo casi el mismo número de la Cámara que aprobó el acto para presentar la acción de inconstitucionalidad. Esto es inaudito toda vez que los medios de control constitucional tienen como medio primordial que no se viole la Constitución, entonces los candados procedimentales tendrían que ser mínimos, ya que no quiere decir que si algo fuere impugnado tiene que ser declarado inconstitucional.

El porcentaje tan alto del mismo órgano que emite la norma general quizá se sustenta en la relevancia de la voluntad popular reflejada por los legisladores ejerciendo la soberanía, lo cual hace más trascendente la actuación del Poder Judicial de la Federación en estos temas. En ese mismo tenor, se ha tenido mucho recelo en cuanto a qué actores del Gobierno se legitimará en estos medios de control. Fue hasta el año 2006 que se legitimó a la Comisión Nacional de los Derechos Humanos ${ }^{52}$ para impugnar leyes federales, locales y tratados internacionales siempre que vulneren derechos humanos; y en 2016 también se facultó a los organismos de protección de derechos humanos locales para impugnar normas de las entidades federativas

51 Sergio López-Ayllón y Florencio Valladares. Las acciones de inconstitucionalidad en la Constitución mexicana: balance empírico de doce años de ejercicio. REVISTA CUESTIONES CONSTITUCIONALES 21. Julio-diciembre 2009. Pág. 183. doi: http://dx.doi. org/10.22201/iij.24484881e.2009.21.5883. Disponible en: https://revistas.juridicas. unam.mx/index.php/cuestiones-constitucionales/article/view/5883. Incluso los autores se refieren a este proceso como "una especie de control constitucional previo" ya que no lo es.

52 Diario Oficial de la Federación, 14 de septiembre de 2006. Disponible en: https://archivos.juridicas.unam.mx/www/legislacion/federal/reformas/14092006.pdf 
relacionadas con su materia ${ }^{53}$. En esa última reforma, se facultó al Instituto Nacional de Transparencia, Acceso a la Información y Protección de Datos Personales para impugnar las normas de su competencia. Así mismo, se otorgó competencia procedimental a los organismos garantes equivalentes en las entidades federativas, en contra de leyes expedidas por las Legislaturas locales ${ }^{54}$. En la reforma referida, se estableció que el fiscal general de la República seguiría legitimado para promover, pero solo respecto a leyes federales y de las entidades federativas, en materia penal y procesal penal, así como las relacionadas con el ámbito de sus funciones ${ }^{55}$.

La legitimidad del procurador general fue dudosa desde 1994, ya que estaba facultado para impugnar tratados internacionales ${ }^{56}$, pero el que los firmaba y negociaba era el presidente de la República, que era su jefe inmediato y que lo podía remover libremente. Después, se modificó el artículo 102 y mutó la institución a fiscal general, que es nombrado por el Senado al igual que el fiscal encargado de Delitos Electorales y el de Anticorrupción, el cual tiene duración de nueve años en el cargo; es decir, no importará qué presidente llegue o la tendencia política (el presidente dura seis años en el cargo $^{57}$ ), el fiscal puede ser removido por el mismo Senado. Pero de nuevo en México lo político rebasa a lo jurídico, toda vez que el penúltimo presidente de la República, en el 2018, permitió que el actual presidente, perteneciente a otro partido político, eligiera a los tres fiscales referidos, anulando con ello el fin de lo señalado por la Constitución en el artículo $102^{58}$ y la idea del artículo 105. Todo para que el fiscal general pudiera, como órgano autónomo, impugnar los tratados internacionales revisados por el presidente y su consejero y ratificados por el Senado ${ }^{59}$. No obstante lo anterior, se optó en 2016 por eliminar dicha facultad.

53 Diario Oficial de la Federación, 29 de enero de 2016. Disponible en: https://www.dof. gob.mx/nota_detalle.php?codigo $=5424043 \&$ fecha $=29 / 01 / 2016$

54 Artículo 105 constitucional, Inciso h).

55 Ibid., Fracción II, Inciso i).

56 Artículo 105, Fracción II, Inciso c).

57 Artículo 83: "El Presidente entrará a ejercer su encargo el 10. de octubre y durará en él seis años [...]".

58 Artículo 102A: "El Ministerio Público de la Federación se organizará en una Fiscalía General de la República como órgano público autónomo, dotado de personalidad jurídica y patrimonio propio [...]".

59 Artículo 76: "Son facultades exclusivas del Senado: I. Analizar la política exterior desarrollada por el Ejecutivo Federal con base en los informes anuales que el Presidente de la República y el Secretario del Despacho correspondiente rindan al Congreso. Además, aprobar los tratados internacionales y convenciones diplomáticas que el Ejecutivo Federal suscriba, así como su decisión de terminar, denunciar, suspender, modificar, enmendar, retirar reservas y formular declaraciones interpretativas sobre los mismos [...]". 
En la reforma original, en los incisos a) b) d) y e) de la fracción II se estableció que una minoría integrante del mismo órgano del que emana la ley o que ratifica el tratado puede impugnar por esta vía. Ahora bien, se mantuvo ese $33 \%$ respecto a los incisos a) b) y d), que como señalamos antes es un porcentaje alto. Se considera en esa tesitura que en la reforma de 2016 se pudo bajar el porcentaje o, mejor aún, implementar que algún órgano constituido cuestionara una norma general emanado de otro ${ }^{60}$, aunado al hecho de que -en principio - todos deberían estar legitimados, incluidos los ciudadanos, ya que es un interés común que se conserve el orden jurídico.

Otra cosa que se pudo corregir en la reforma del año 2016 deviene de 1996, cuando se estableció que los partidos políticos están legitimados para impugnar leyes electorales ${ }^{61}$. En 1999, se emitió un criterio controvertido por parte de la Suprema Corte de Justicia de la Nación; se señalaba que, no obstante decir la Constitución expresamente que están legitimados los partidos políticos para impugnar normas electorales, ellos no eran los únicos legitimados ${ }^{62}$. En su momento, recibió muchas críticas y se le acusó de ser un legislador activo y de exceder su interpretación añadiendo a la norma constitucional supuestos que no señalaba. Ahora bien, en la reforma de 2016, aunque se conocía el criterio referido, se replica casi exactamente igual cambiando solo dos palabras (y estamos de acuerdo en que es un acierto): estatal y Estado por entidad federativa, pero conservaron la esencia del mismo texto de veinte años antes, sin señalar que no son los únicos legitimados por los partidos políticos, también los dos párrafos finales de la reforma de 1996 se conservan idénticos, pero cambiaron de lugar en orden del artículo.

Consideramos, en cuanto a la organización actual de nuestro sistema de justicia, que las acciones de inconstitucionalidad en materia electoral tendrían que ser resueltas por el Tribunal Electoral del Poder Judicial de la Federación, que son quienes conocen la materia, incluso al resolver actualmente la Suprema Corte de Justicia de la Nación puede pedir opinión a la Sala Superior de ese Tribunal sobre la norma en disputa ${ }^{63}$.

60 Erick Francisco Tapia Hernández, supra, nota 46, pág. 135.

61 En el Diario Oficial de la Federación del 22 de agosto de 1996, se implementó el inciso f) de la fracción II del artículo 105 Constitucional, https://archivos.juridicas.unam.mx/ www/legislacion/federal/reformas/rc136.pdf

62 Tesis: P./J. 27/99, Rubro "Acción de inconstitucionalidad. los partidos políticos no son los únicos que pueden combatir en esta vía leyes electorales". Semanario Judicial de la Federación y su Gaceta, Novena Época, Tomo IX, Abril de 1999, Pág. 253

63 Artículo 68 de la Ley Reglamentaria de las Fracciones I y II del artículo 105 de la Constitución Política de los Estados Unidos Mexicanos. 


\section{JUICIO DE AMPARO}

Describir el amparo en pocas líneas es todo un reto; sin embargo, abordaremos las ideas principales de qué es y cómo funciona, así como algunas particularidades en lo procesal.

La Suprema Corte lo describe como un medio jurisdiccional protector de los derechos humanos establecidos en la Constitución Política de los Estados Unidos Mexicanos y en los tratados internacionales de los que México sea parte ${ }^{64}$. La procedencia la describe la Constitución en tres supuestos:

I. Por normas generales, actos u omisiones de la autoridad que violen los derechos humanos reconocidos y las garantías otorgadas para su protección por esta Constitución, así como por los tratados internacionales de los que el Estado Mexicano sea parte;

II. Por normas generales o actos de la autoridad federal quevulneren o restrinjan la soberanía de los Estados o la autonomía de la Ciudad de México,y III. Por normas generales o actos de las autoridades de las entidades federativas que invadan la esfera de competencia de la autoridad federal. ${ }^{65}$

En las fracciones II y III, la vulneración de la soberanía y la invasión de competencias deben implicar violación de derechos humanos para su procedencia, pero la hipótesis genérica es la fracción I.

En ese sentido, el juicio de amparo es un medio de control constitucional que procede contra actos de autoridad incluyendo normas generales, del cual pueden hacer uso los ciudadanos; a partir del año 2013, tiene una reforma sustancial en la Ley de Amparo ${ }^{66}$ que permite la procedencia también contra omisiones. Las normas pueden impugnarse cuando estas van a tener vigencia de manera inminente, es decir, de forma autoaplicativa o de forma heteroaplicativa, esto es, a posteriori, cuando ya se aplicó el acto de autoridad establecido en la ley ${ }^{67}$. Cabe señalar que el autoaplicativo no es un medio de control previo, ya que en ese caso la ley ya fue publicada pero está pendiente su entrada en vigor de acuerdo con lo que indique la misma norma en los transitorios o no se ha llevado a cabo el primer acto de aplicación.

64 ¿Qué hace la Suprema Corte de Justicia de la Nación? Disponible en: https://www.scjn. gob.mx/conoce-la-corte/que-hace-la-scjn

65 Artículo 103 Constitucional.

66 Publicada en el Diario Oficial de la Federación el 2 de abril de 2013 http://www.diputados.gob.mx/LeyesBiblio/abro/lamp/LAmp_abro_02abr13.pdf

67 Artículo 17 de la Ley de Amparo. 
Tenemos dos tipos de amparo: el indirecto, que procede contra leyes y actos de autoridad fuera de juicio68; y el amparo directo, que procede contra resoluciones que ponen fin a un procedimiento. Del primero se conoce por lo general un juez de Distrito y del segundo, un Tribunal Colegiado de Circuito. Por lo que hace, el primero es llamado biinstancial ${ }^{69}$, porque contra la sentencia de amparo indirecto procede el recurso de revisión del cual conocen los Tribunales Colegiados de Circuito, que suelen ser la última instancia en el amparo. Sin embargo, existe un recurso extraordinario que procede contra las sentencias de amparo directo en el que no se haya hecho una interpretación de la Constitución o tratados internacionales, o que se haya omitido siempre y cuando se haya solicitado la interpretación en los conceptos de violación del amparo que dio origen al recurso de revisión y que aparte resulten en un criterio importante y trascendente ${ }^{70}$. No obstante, no existe en México una pragmática de neoconstitucionalismo aplicada; muchas veces los argumentos y la trascendencia se pueden resolver de manera subjetiva o políticamente correcta, estos últimos son competencia de las Salas de la Suprema Corte.

Se puede observar que México tiene un sistema mixto. Por un lado, existe la jurisprudencia que tiene una fuerza máxima ${ }^{71}$ y la Suprema Corte resuelve los medios de control que se estudian, los primeros dos exclusivamente en Pleno y el amparo en Salas, reforzando lo centralizado y concentrado en el control; sin embargo, los jueces de Distrito ${ }^{72}$ y los magistrados de Tribunal Colegiado que son federales pueden inaplicar o dictar la inconstitucionalidad de una norma ${ }^{73}$, y en el año 2013 se crearon los Plenos de Circuito $^{74}$, abonando al establecimiento del control difuso, aunque en caso

68 Ibid. Artículo 170.

69 Ibid. Artículo 107.

70 Artículo 107, Fracción IX, de la Constitución Política de los Estados Unidos Mexicanos; artículo 21, Fracción III, Inciso a), de la Ley Orgánica del Poder Judicial de la Federación; los puntos primero y segundo del Acuerdo General Plenario 5/1999, así como el artículo 86 de la Ley de Amparo.

71 Es obligatoria para todos los jueces del país según el artículo 94 constitucional y el artículo 217 de la Ley de Amparo, que establece para quién es obligatoria la jurisprudencia. Señala el primer párrafo: "La jurisprudencia que establezca la Suprema Corte de Justicia de la Nación, funcionando en Pleno o en Salas, es obligatoria para estas tratándose de la que decrete el Pleno, y además para los Plenos de Circuito, los tribunales colegiados y unitarios de circuito, los juzgados de distrito, tribunales militares y judiciales del orden común de los Estados y del Distrito Federal, y tribunales administrativos y del trabajo, locales o federales [...]"

72 Recientemente, hubo una sentencia que fue emitida por un juez de distrito en el que aprobaba el uso lúdico de la cocaína, aunque citó los criterios emitidos por la Primera Sala de la Suprema Corte de Justicia de la Nación en el uso lúdico de la marihuana.

73 En nuestro derecho se ha asumido como sinónimo inconstitucional y anticonstitucional.

74 Los Circuitos los determina el Consejo de la Judicatura Federal que también fue creación de la reforma del año 1994. 
de contradicción, lo que diga la Corte debe prevalecer. No obstante, hay voces que refieren que lo anterior no es algo que valga la pena estudiarse y que "el valor explicativo de los adjetivos difuso y concentrado ha perdido importancia en la actualidad"75. Consideramos que no es una cuestión de forma sino de fondo para saber qué jueces serán los competentes en control e interpretación constitucional.

El juicio de amparo se tiene como una innovación mexicana ${ }^{76}$; sin embargo, ha sido tratado como un medio de defensa omnipotente; verbigracia, se señala en el artículo 25 de la Convención Americana relacionado con la protección judicial que:

1. Toda persona tiene derecho a un recurso sencillo y rápido o a cualquier otro recurso efectivo ante los jueces o tribunales competentes, que la ampare contra actos que violen sus derechos fundamentales reconocidos por la Constitución, la ley o la presente Convención, aun cuando tal violación sea cometida por personas que actúen en ejercicio de sus funciones oficiales. ${ }^{77}$

Al respecto, el Poder Judicial indicó que el amparo es el recurso efectivo al que se refiere el artículo 25 de la Convención Americana sobre Derechos Humanos ${ }^{78}$, y en efecto es el medio idóneo, en realidad no porque lo sea, sino porque es el único.

Cabe mencionar que había un atraso importante con la reforma de derechos humanos de 2011, ya que no obstante se hizo una respecto al Poder Judicial de la Federación ${ }^{79}$, la Ley de Amparo se expidió hasta el año 2013. En esa reforma, verbigracia, se incluyó para la procedencia del amparo el reconocimiento de un interés

75 Francisco Fernández Segado. LA JUSTICIA CONSTITUCIONAL ANTE EL SIGLO XXI: LA PROGRESIVA CONVERGENCIA DE LOS SISTEMAS AMERICANO Y EUROPEO-KELSENIANO. Editorial Universidad Nacional Autónoma de México. (2004). Pág. 27.

76 El primer antecedente lo tenemos en el proyecto de la Constitución de Yucatán en 1840. Véase: Luciano Silva Ramírez. EL CONTROL JUDICIAL DE LA CONSTITUCIONALIDAD Y EL JUICIO DE AMPARO EN MÉXICO. Editorial Porrúa. (2008). Págs. 171-172.

77 Convención Americana sobre Derechos Humanos. Disponible en: https://www.oas.org/ dil/esp/tratados_b-32_convencion_americana_sobre_derechos_humanos.htm

78 Tesis: II.8o. (I Región) 2 K, Rubro: "Juicio de amparo. Al seguirse conforme a los artículos 103 y 107 de la Constitución Federal, a partir de su reforma publicada en el Diario Oficial de la Federación el 6 de junio de 2011, puede considerarse como el recurso efectivo a que se refiere el artículo 25 de la Convención Americana sobre Derechos Humanos". Gaceta del Semanario Judicial de la Federación, Décima Época, Libro XIII, Tomo 4, Registro 2001955, octubre de 2012, página 2622.

79 Diario Oficial de la Federación, 6 de junio de 2011, decreto por el que se reforman, adicionan y derogan diversas disposiciones de los artículos 94, 103, 104 y 107 de la Constitución Política de los Estados Unidos Mexicanos. Disponible en: http://www.dof. gob.mx/nota_detalle.php?codigo=5193266\&fecha=06/06/2011 
legítimo; antes solo se había establecido el interés jurídico. Si bien el artículo 17 constitucional en 2010 establecía la existencia de acciones colectivas, en lugar de crear una ley específica de la materia, se incluyó en el Código Federal de Procedimientos Civiles $^{80}$, por lo cual existe el interrogante de cómo se resolvían los asuntos de derechos difusos previos a 2010.

En ese sentido, tenemos que el amparo procede contra actos de autoridad en materia ambiental ${ }^{81}$ mediante el amparo colectivo con base en la Ley de Amparo, y sobre esos mismos temas en caso de que el vulnerador sea un particular proceden las acciones colectivas para lo cual se utiliza el Código Federal de Procedimientos Civiles. Por ende, la ley no atiende a la naturaleza del acto, sino a los participantes en este, no se litiga por materia sino por actores, toda vez que apenas se está reconociendo en México la eficacia horizontal de los derechos humanos. Sin embargo, a partir de la reforma de 2013 el amparo procede contra actos y omisiones de la autoridad o los particulares, pero siempre y cuando estos actúen como tal por ministerio de ley ${ }^{82}$. A partir de lo anterior, se advierte que el amparo no procede contra cualquier acto de un particular; tiene que ser un particular que de acuerdo con la ley tenga una relación de supra a subordinación y que sus actos sean considerados como actos de autoridad, hipótesis que en la especie mencionada no se actualiza.

Respecto a la finalidad del juicio de amparo, es restituir al quejoso ${ }^{83}$ en el pleno goce del derecho violado, restableciendo las cosas al estado que guardaban antes de la violación, y si es de omisión, obligando a la autoridad responsable a respetar el derecho de que se trate y a cumplir lo que este exija ${ }^{84}$.

En relación con dicha finalidad, existen casos que han suscitado preguntas, verbigracia, la desaparición forzada de personas, que al ser perpetrada por el Estado

80 Artículo 17: "El Congreso de la Unión expedirá las leyes que regulen las acciones colectivas. Tales leyes determinarán las materias de aplicación, los procedimientos judiciales y los mecanismos de reparación del daño. Los jueces federales conocerán de forma exclusiva sobre estos procedimientos y mecanismos [...]".

81 Estos son los únicos derechos difusos protegidos por nuestro derecho. Véase: Erick Francisco Tapia Hernández. La omisión de protección en diversas materias mediante acciones colectivas en el Estado mexicano. REVISTA JURíDICA 6. Julio-diciembre 2018. Pág. 59 y ss. Disponible en: http://revistajuridica.uas.edu.mx/Revistajus6/REVISTA\%20 JUS\%2OVOLUMEN\%202\%20no.\%206.pdf

82 Tesis: XVI.10.A.22 K, Aislada, Rubro: "Actos de particulares. Para considerarlos equivalentes a los de autoridad conforme al artículo 5o., Fracción II, segundo párrafo, de la Ley de Amparo, deben reunir las características de unilateralidad, imperio y coercitividad, además de derivar de una relación de supra a subordinación". Gaceta del Semanario Judicial de la Federación, Décima Época, Libro 19, Tomo III, Registro: 2009420, junio de 2015, página 1943.

83 Aquel que promueve el juicio de amparo. Artículo 5 de la Ley de Amparo.

84 Ibid. Artículo 77. 
y ser un hecho ilícito, abre paso a dos preguntas: la primera, en relación a qué actuar le pedimos a la autoridad conforme a la ley; y la segunda, a si es posible que se configure o no alguna omisión. En esa tesitura, la respuesta que proporcionó el Poder Judicial de la Federación fue que si bien es cierto es un ilícito, se trata de un actuar irregular de la autoridad y por tanto procede el juicio de amparo y el quejoso puede presentarlo por conducto de algún tercero ${ }^{85}$. Con este tipo de hipótesis, se advierte que el amparo ha sido insuficiente y ha tratado de adaptarse a la realidad por medio de jurisprudencia ${ }^{86}$.

En virtud de lo anterior, se presume que antes de la reforma y ahora en ocasiones los gobernados optan por acudir a la Comisión Nacional de los Derechos Humanos, dado que aunque sus recomendaciones no son coercibles, emite medidas cautelares eficientes. Por ejemplo, cuando una mujer transexual con caracteres biológicos masculinos es enviada a un reclusorio varonil, ante la alta probabilidad de que la violen, se solicitan medidas cautelares a la Comisión para que la separen inmediatamente de la población del reclusorio. O cuando ayudan a que se proporcione un medicamento a los particulares cuando las instituciones de salud públicas se rehúsan o se niegan a proporcionarlo, se dictan medidas cautelares o recomendaciones que a veces incluso tardan menos que un juicio de amparo.

Si bien es cierto que en el amparo se puede conceder la suspensión, esta se complica porque tiene particularidades respecto a exhibir una fianza, por ejemplo; pero lo más difícil es que los efectos tienen que estar detallados por la autoridad que los concede y no son homogéneos, son dependiendo del caso y del criterio del juzgador.

Aunado a las deficiencias enunciadas, el amparo no procede de manera expresa contra lo siguiente:

Contra adiciones o reformas a la Constitución Política de los Estados Unidos Mexicanos ${ }^{87}$, este tema exigiría por todos los operadores jurídicos saber qué derecho es contrario a la norma, deben tener un alto nivel de

85 Ibid. Artículo 15: "Cuando, por las circunstancias del caso o lo manifieste la persona que presenta la demanda en lugar del quejoso, se trate de una posible comisión del delito de desaparición forzada de personas, el juez tendrá un término no mayor de veinticuatro horas para darle trámite al amparo, dictar la suspensión de los actos reclamados, y requerir a las autoridades correspondientes toda la información que pueda resultar conducente para la localización y liberación de la probable víctima. Bajo este supuesto, ninguna autoridad podrá determinar que transcurra un plazo determinado para que comparezca el agraviado, ni podrán las autoridades negarse a practicar las diligencias que de ellas se soliciten o sean ordenadas bajo el argumento de que existen plazos legales para considerar la desaparición de una persona".

86 Ibid. Artículo 61

87 Ibid. Fracción I. 
conocimiento en argumentación, interpretación y lógica jurídica, es muy lamentable y exhibe ante la comunidad internacional que a pesar de que la décima época implementó o anhelaba implementar el neoconstitucionalismo en México, no se ha logrado. Es una muestra más de que solo se puede litigar con lo que diga la ley, una contradicción que parece una hilaridad, si el control de la constitucionalidad existe para que no se viole la Constitución, violar la misma y su revisión queda subsumida a la validez de la norma como se hacía hace cien años con los positivistas clásicos. Las reformas por lo menos en México, quedan a mayoriteo de las Cámaras y son múltiples las violaciones que se han realizado en contra de los pilares democráticos incluyendo los derechos humanos y solo por encontrarse regulada la reforma en la Constitución se tiene que acabar por lo menos jurídicamente ante tribunales la discusión o como el caso señalado la discusión se ceñirá a la academia, dando al legislador un protagonismo exactamente igual que hace un siglo imposibilitando mutar de un Estado legalista a uno Constitucional.

Por eso en México discutir de reformas constitucionales formalmente que a la vez sean inconstitucionales materialmente es legalmente imposible, ya que aún subsiste un sistema positivista que en la práctica sigue teniendo vigencia ante la insuficiencia de un plan de aplicación del nuevo paradigma surgido a partir del año 2011. Por cierto, tampoco es procedente el control constitucional de la jurisprudencia. ${ }^{88}$

En ese orden de ideas, en el año 2013 en vez de optar por implementar la hipótesis referida, se optó por prohibirla. Al respecto, hay un criterio que llama mucho la atención, más porque fue dictado en la era del "neopositivismo" a la luz de la décima época que refiere: "El juicio de amparo es uno de los mecanismos a través de los cuales se hace efectiva la supremacía constitucional, la cual hace de la Ley Fundamental el referente de validez de la producción normativa que se somete a juicio; de ahí que, por ser autorreferente, la Carta Magna no puede ser juzgada a la luz de ella misma"89. Desde luego, esto es erróneo si se limita desde la postura teórica positivista, y si

88 Tesis: 2a. Cll/2016 (10a.), Rubro: "Jurisprudencia emitida por la Suprema Corte de Justicia de la Nación. No es susceptible de sujetarse a control constitucional". Gaceta del Semanario Judicial de la Federación, Décima Época, Libro 35, octubre de 2016, Tomo I, página 928.

89 Tesis: I.180.A.3 CS, Rubro: "Adiciones o reformas a la Constitución Federal. Es improcedente el juicio de amparo en su contra". Gaceta del Semanario Judicial de la Federación, Décima Época, Libro 35, Tomo IV, octubre de 2016, página 2833. 
se quiere contrastar el texto contra el texto y la jerarquía de normas, no se va a poder; este criterio es un claro referente de que en nuestro país equiparan lo que es derecho, justicia, ley y norma. Por otro lado, reconoce implícitamente que el juicio de amparo no es el mecanismo adecuado, con eso estamos de acuerdo, ya que se requiere uno particular, debido a la imposibilidad de acudir a otra vía para impugnar, simplemente porque no existe otra.

No procede tampoco contra actos de la Suprema Corte de Justicia de la Nación ni contra actos del Consejo de la Judicatura Federal ${ }^{90}$. Por ello, se hace patente la necesidad de contar con un órgano de control político independiente del Poder Judicial de la Federación, con el fin de que los actos del Poder Judicial también sean revisables y no violen la Constitución, más cuando se cuestiona la independencia de los integrantes del Poder Judicial de la Federación como en México ${ }^{91}$.

Tampoco procede contra resoluciones dictadas por el Tribunal Electoral del Poder Judicial de la Federación ${ }^{92}$, o contra las resoluciones o declaraciones de las autoridades competentes en materia electoral ${ }^{93}$. Sin embargo, pueden violarse garantías y derechos humanos en todos los procedimientos establecidos en el país, incluyendo los asuntos electorales, y a excepción de las acciones de inconstitucionalidad contra leyes en materia electoral, se encargará el Tribunal Electoral del Poder Judicial de la Federación, debido a dos razones debatibles: la primera es para evitar que la Suprema Corte de Justicia de la Nación se inmiscuya en asuntos políticos (cuando irónicamente esa es la función de los Tribunales Constitucionales); y la segunda es que al instituir el Tribunal Electoral, lo dejaron dentro del mismo Poder Judicial de la Federación con la finalidad de evitar crear un cuarto poder.

El juicio de amparo no procede tampoco:

Contra actos del Congreso de la Unión, su Comisión Permanente o cualquiera de sus Cámaras en procedimiento de colaboración con los otros poderes que objeten o no ratifiquen nombramientos o designaciones para ocupar cargos, empleos o comisiones en entidades o dependencias de la Administración Pública Federal, centralizada o descentralizada,

90 Artículo 61, Fracciones II y III de la Ley de Amparo.

91 La integración del Consejo de la Judicatura es de los tres poderes, pero el titular es el presidente de la Suprema Corte de Justicia de la Nación, lo cual compromete la imparcialidad en la Sanción de los Funcionarios del Poder Judicial de la Federación. Artículo 100 constitucional.

92 Artículo 61, Fracción IV de la Ley de Amparo.

93 Ibid. Fracción XV. 
órganos dotados de autonomía constitucional u órganos jurisdiccionales de cualquier naturaleza. ${ }^{94}$

Contra las resoluciones o declaraciones del Congreso Federal o de las Cámaras que lo constituyen, de las Legislaturas de los Estados o de sus respectivas Comisiones o Diputaciones Permanentes, en declaración de procedencia y en juicio político, así como en elección, suspensión o remoción de funcionarios en los casos en que las Constituciones correspondientes les confieran la facultad de resolver soberana o discrecionalmente. ${ }^{95}$

Al respecto, cabe precisar que la declaración de procedencia funciona en México porque tenemos vigente el fuero material; el único que tenemos prohibido es el fuero personal ${ }^{96}$. Para darse una idea de lo que sucede en México políticamente, veremos lo referente a la discusión sobre eliminar el fuero. El 27 de marzo de 2019, el Senado aprobó eliminar el fuero al presidente de la República e incluyeron a diputados y senadores ${ }^{97}$; posteriormente, en octubre los diputados aprobaron dichas reformas ${ }^{98}$ para que finalmente, a principios de diciembre, el Senado rechazara la propuesta porque el dictamen no incluía a los legisladores ${ }^{99}$ y se dejó pendiente el tema.

Con lo anterior, en México la declaración de procedencia y el juicio político funcionan en mayoriteo de las Cámaras; por ende aunque un servidor público con fuero sea culpable, si tiene mayoría en la Cámara, la declaración no procederá; y en el caso contrario, un servidor público con fuero puede ser inocente pero si tiene enemigos políticos que sean mayoría en la Cámara, se le puede juzgar ${ }^{100}$, con lo irracional del caso de que ambos procedimientos permiten presentar pruebas ante la Cámara e

\section{Ibid. Fracción V.}

95 Ibid. Fracción VII.

96 Artículo 13 constitucional: "Ninguna persona o corporación puede tener fuero [...].

97 Silvia Arellano. Senado aprueba reforma para quitar fuero a Presidente y legisladores. MILENIO. 26 de noviembre de 2020. Disponible en: https://www.milenio.com/politica/ senado-aprueba-reforma-eliminar-fuero-presidente

98 EL UNIVERSAL. Diputados aprueban reforma para eliminar fuero al presidente. 29 de octubre de 2019. Disponible en: https://www.eluniversal.com.mx/nacion/politica/diputados-aprueban-reforma-para-eliminar-fuero-al-presidente

99 Neldy San Martín. Senado rechaza eliminar fuero al presidente porque el dictamen no incluye a legisladores. PRoceso. 3 de diciembre de 2019. Disponible en: https:// www.proceso.com.mx/609330/senado-rechaza-eliminar-fuero-al-presidente-porque-el-dictamen-no-incluye-a-legisladores

100 La Constitución y la ley señalan que en la declaración de procedencia solo intervendrá la Cámara de Diputados y en el juicio político, ambas. 
incluso defensa de abogado. Se debería establecer un recurso en que el que por lo menos el máximo órgano del poder judicial los revisara en cuanto a violaciones al procedimiento o derechos sustantivos ${ }^{101}$; eso no sucede, por el contrario está prohibido de manera expresa y así lo señala también la Constitución en el artículo 110, último párrafo ${ }^{102}$. Es de resaltar que también los miembros del Poder Judicial Federal y Local pueden ser sancionados, lo que podría dar lugar a persecuciones políticas, como ha sucedido ${ }^{103}$.

Abundando sobre el particular, señala la ley en la materia que procede el juicio político contra actos u omisiones de los servidores públicos señalados en el artículo 110 que redunden en perjuicio de los intereses públicos fundamentales o de su buen despacho, entendiendo por ello los siguientes: el ataque a las instituciones democráticas; el ataque a la forma de gobierno republicano, representativo, federal; las violaciones a los derechos humanos; el ataque a la libertad de sufragio; la usurpación de atribuciones; cualquier infracción a la Constitución o a las leyes federales cuando cause perjuicios graves a la Federación, a uno o varios estados de la misma o de la sociedad, o motive algún trastorno en el funcionamiento normal de las instituciones; las omisiones de carácter grave, en los términos de la fracción anterior; y las violaciones sistemáticas o graves a los planes, programas y presupuestos de la Administración Pública Federal o de la Ciudad de México y a las leyes que determinan el manejo de los recursos económicos federales y de la Ciudad de México ${ }^{104}$. Casi todas las causales son subjetivas y hacen más fácil el mayoriteo en contra o a favor de un servidor público que sí haya cometido el acto, pero no lo sancionan si las Cámaras son de su partido. La ley se convierte en este caso en una herramienta política contra lo que no procede nada.

No procede tampoco contra normas generales respecto a las cuales la Suprema Corte de Justicia de la Nación haya emitido una declaratoria general de

101 Véase: Tesis: I.8o.C. J/2, Rubro: "Derechos sustantivos. Su diferencia con los derechos adjetivos". Gaceta del Semanario Judicial de la Federación, Décima Época, Libro 40, Tomo IV, marzo de 2017, página 2416.

102 Artículo 110 constitucional: "Podrán ser sujetos de juicio político los senadores y diputados al Congreso de la Unión, los ministros de la Suprema Corte de Justicia de la Nación [...]. Las declaraciones y resoluciones de las Cámaras de Diputados y Senadores son inatacables".

103 Uno de los casos más relevantes fue el caso de Marisela Escobedo. Véase: Omar Granados. Jueces de Chihuahua piden asilo en EU. ANIMAL PoLítIco. 12 de enero de 2011. Disponible en: https://www.animalpolitico.com/2011/01/jueces-de-chihuahuapiden-asilo-en-eu-tras-inicio-de-juicio-politico/

104 Artículos 5, 6 y 7 de la Ley Federal de Responsabilidades de los Servidores Públicos. Disponible en: http://www.secretariadoejecutivo.gob.mx/docs/pdfs/normateca/Leyes/ ley_federal_responsabilidades.pdf 
inconstitucionalidad ${ }^{105}$. Esta es una implementación que hace la reforma de 2013. Es criticable que un medio de defensa como el juicio de amparo sea de difícil acceso al ciudadano, toda vez que requiere conocimientos acerca de la violación constitucional de un acto de autoridad y el recurso económico para contratar un abogado o en su defecto conocer cómo funcionan las defensorías públicas. La crítica se incrementa porque durante años se tuvo la relatividad de las sentencias de amparo y se conserva, en la que solo se protegía al quejoso que acudía en busca de la justicia aunque el acto fuera una ley declarada inconstitucional, así fueran miles de personas a las que se les estuviera violando un derecho. La sentencia, a pesar de que declarara una ley o artículos como inconstitucionales, se dejaba de aplicar solo a los que se fueran al amparo y a sabiendas de que era inconstitucional, se seguía aplicando a toda la población. Ahora cuando las Salas o el Pleno de la Corte resuelvan por segunda ocasión la inconstitucionalidad de una norma general, notificará al emisor de la norma, a excepción de la materia tributaria. Si se ha fijado jurisprudencia por reiteración, se otorgará al órgano emisor de la norma noventa días para que modifique o derogue la norma declarada inconstitucional. El Pleno de la Suprema Corte de Justicia de la Nación emitirá la declaratoria general de inconstitucionalidad ${ }^{106}$ correspondiente siempre que hubiera sido aprobada por mayoría de cuando menos ocho votos. Se publicará en el Diario Oficial de la Federación y la norma no podrá ser aplicada en el país ${ }^{107}$.

No procede el amparo contra actos que no afecten los intereses jurídicos o legítimos del quejoso, ni contra normas generales que requieran de un acto de aplicación posterior al inicio de su vigencia108; ni contra actos consentidos expresamente o por manifestaciones de voluntad que entrañen ese consentimiento; entendiéndose por tales aquellos contra los que no se promueva el juicio de amparo dentro de los plazos previstos $^{109}$. Debe hacerse un análisis minucioso sobre el tiempo de impugnación, sobre todo en temas de derechos difusos y sectores vulnerables, y más en un país que es tan desigual. Pensemos en alguna comunidad que hable dialecto alejado en las montañas y cuyos derechos están siendo vulnerados; no puede compararse con una empresa que tiene un ejército de abogados especialistas para atender las violaciones de derechos. El acto se consiente no por voluntad, sino por factores exógenos.

105 Artículo 61, Fracción VIII de la Ley de Amparo.

106 Incluso cuenta con un sistema de seguimiento de declaratoria general de inconstitucionalidad. Disponible en: http://www2.scjn.gob.mx/denunciasincumplimiento/ConsultaGenerales.aspx

107 Artículo 231 y 232 de la Ley de Amparo.

108 Ibid. Artículo 61, Fracción XII.

109 Ibid. Fracciones XIII y XIV. 
Procedimentalmente, hay ocasiones en que la ley no es clara respecto a los supuestos jurídicos que contiene. La ley permite impugnar en dos momentos, como señalamos: cuando se publica la ley y su violación será inminente o cuando se realice el primer acto de aplicación ${ }^{110}$. Pero ante el supuesto de que no sea clara la aplicación, afectación o primer acto de aplicación, muchos litigantes impugnan de forma autoaplicativa y se los desechan por requerir un acto de aplicación para la afectación; y otros impugnan en el acto de aplicación de forma heteroaplicativa y se los desechan por considerar que debió ser autoaplicativo ${ }^{111}$. Un tema como la violación de derechos humanos no debe ser tan discrecional, debe establecerse la aplicación detallada en la norma.

Otro punto relevante es la improcedencia del amparo cuando se haya consumado la violación de derechos humanos y sean de imposible reparación, ya que no da derecho a indemnización, sino a intentar otra vertiente procedimental112; lo mismo ocurre si la imposible reparación se da en el procedimiento, únicamente se sobresee el asunto ${ }^{113}$.

Otra fracción que ha causado conflictos por la confusión es la que se refiere a la procedencia del amparo cuando todavía hay un recurso de acuerdo con la ley de origen, independientemente del tipo de acto o materia en la que mediante el recurso o medio de defensa legal por virtud del cual puedan ser modificados, revocados o nulificados. Señala la misma ley que no existe obligación de agotar tales recursos o medios de defensa, entre otras hipótesis, si el acto reclamado carece de fundamentación, cuando solo se aleguen violaciones directas a la Constitución ${ }^{114}$.

Jurídicamente, siempre que se hable de actos inconstitucionales se alegará una violación directa a la Constitución, y para armonizarse con el artículo 1, debe señalar derechos humanos también. Tampoco deben agotarse los recursos cuando sean actos que importen peligro de privación de la vida, ataques a la libertad personal fuera de procedimiento, incomunicación, deportación o expulsión, proscripción o

110 lbid. Fracción XIV.

111 Ya hemos tenido casos de confusión máxima, por ejemplo, cuando no teníamos regulado en el país la procedencia contra particulares en la ley. El caso del Registro Nacional de Usuarios de Telefonía Móvil (RENAUT), que consistió en un decreto que duró un año para entrar en vigor desde su publicación, y las compañías telefónicas como particulares cortaban el servicio si el gobernado no proporcionaba sus datos personales. Aquí el problema real era que una vez teniendo vigencia la ley consideraban que no existía el acto de autoridad si materialmente las compañías telefónicas no habían cortado el servicio.

112 Artículo 61, Fracción XVI de la Ley de Amparo.

113 Ibid. Artículo 63, Fracción v.

114 Ibid. Artículo 61, Fracción xx. 
destierro, extradición, desaparición forzada de personas o penas inusitadas ${ }^{115}$. Esta fracción en la práctica tampoco ha sido clara. Es conocido empíricamente que los impartidores de justicia tienen mucho trabajo y muchos prefieren desechar o prevenir que admitir el juicio de amparo ${ }^{116}$, pero el mismo Poder Judicial ha señalado que a partir de la reforma de 2011:

[...] se ha conformado un nuevo control de constitucionalidad y convencionalidad en el sistema jurídico mexicano, en el que se reconoce y se obliga a respetar los derechos humanos, favoreciendo en todo tiempo a las personas con la protección más amplia, es válido admitir, como excepción al principio de definitividad, los casos en los que se plantee una violación directa a un derecho humano previsto en la Constitución Política de los Estados Unidos Mexicanos o en los tratados internacionales en los que el Estado Mexicano sea parte.17

En consecuencia, por un lado, se obliga a agotar los medios de defensa y, por otro lado, se puede acudir al amparo directamente esperando que el juez comparta el criterio de que no es necesario agotar el principio de definitividad. Respecto al consenso de asuntos legales procesales, puede ser que no hay problema, se deben agotar mayoritariamente los medios de defensa como la apelación, pero materialmente cuando el juzgador deba considerar el acto, tendrá que hacer una interpretación particular del caso para decidir si es válida o no la procedencia; por ejemplo, cuando un enfermo solicita medicamento, quizá valore el tipo de enfermedad, evolución, entre otras cosas, para admitir y además conceder la suspensión, fundado en esa jurisprudencia, y valorar si está en peligro la vida de acuerdo con la argumentación de los conceptos de violación del amparo.

Otro grave problema es la multiplicidad de criterios sobre un mismo tema que hace que litigar en México sea un acto de fe; por ejemplo, el principio pro persona e interpretación conforme, ambos criterios son obligatorios por ministerio de ley, pero ante la procedencia de muchos amparos de los que antes no tenía conocimiento el

115 Ibid. Fracción XVII.

116 Quizá influye que independientemente del asunto o extensión de la demanda el término del acuerdo es de veinticuatro horas. Ibid. Artículo 112.

117 Tesis: xxx.10.3 K, Rubro: “Definitividad en el amparo. Como excepción a este principio, es innecesario agotar los medios de defensa ordinarios cuando se aduzcan violaciones directas a los derechos humanos contenidos en la Constitución Federal o en los tratados internacionales en que el Estado mexicano sea parte". Semanario Judicial de la Federación y su Gaceta, Décima Época, Libro XVIII, Tomo 3, marzo de 2013, página 1984 
Poder Judicial, a partir de la reforma de $2011^{118}$, en vez de ampliarlos empezó a limitarlos; verbigracia, en la interpretación conforme señala los pasos a seguir para sustentarlo en las sentencias, lo que obliga a que el litigante acredite los pasos emitidos en dicho criterio ${ }^{119}$ y señala también requisitos mínimos para aplicarla120; tampoco basta señalar el principio pro persona para hacerlo valer ${ }^{121}$. Recordemos que la jurisprudencia es obligatoria en los términos señalados en la ley que enunciamos antes, entonces no hay razón de que lo establezcan como obligatorio en la ley para los juzgadores si en la práctica trasladan su aplicación a los litigantes. Y advirtamos que es un juicio que protege derechos humanos y garantías constitucionales, por lo que debería de ser de oficio y de fácil acceso a la población; sin embargo, en la práctica son los litigantes los que tienen que argumentar y comenzar el litigio desde la procedencia del juicio de amparo para su admisión.

Por último, consideramos un atraso importante también en el tema de la omisión legislativa. Ya había criterios que negaban su procedencia, pero hasta el año 2016, se tiene como una innovación que proceda el amparo contra la omisión legislativa cuando hay un artículo, ya sea del texto de la ley o transitorio, que obligue a un órgano particular a legislar en determinado tiempo; es decir, "cuando hay un mandato constitucional o legal que obligue a una autoridad y este no se ha ejecutado"122, no es como en otros países que puede surgir de manera espontánea incluso por parte de los ciudadanos, que han advertido que hace falta que se regule sobre determinada materia.

118 Por ejemplo, el bullying se sustentó en derechos humanos contenidos en tratados internacionales, igual que el uso lúdico de la marihuana.

119 Tesis: P. LXIX/2011, Rubro: "Pasos a seguir en el control de constitucionalidad y convencionalidad ex officio en materia de derechos humanos". Semanario Judicial de la Federación y su Gaceta, Novena Época, Libro III, Tomo 1, diciembre de 2011, página 552.

120 Tesis: 2a./J. 123/2014, Rubro: "Control de constitucionalidad y convencionalidad. su ejercicio debe satisfacer requisitos mínimos cuando se propone en los conceptos de violación". Gaceta del Semanario Judicial de la Federación, Décima Época, Libro 12, Tomo I, noviembre de 2014, página 859.

121 Tesis: IV.2o.A. J/10, Rubro: "Conceptos de violación inoperantes en el amparo directo. Lo son aquellos que, además de no controvertir eficazmente las consideraciones de la sentencia reclamada, se limitan a invocar la aplicación del principio pro persona o del nuevo modelo de control constitucional, como causa de pedir, pero no cumplen con los parámetros mínimos para la eficacia de esta solicitud". Gaceta del Semanario Judicial de la Federación, Décima Época Libro 24, Tomo IV, noviembre de 2015, página 322.

122 Tesis: I.180.A.11 K, Rubro: "Omisión legislativa o reglamentaria. Hipótesis en que es procedente el amparo indirecto". Décima Época, Tomo IV, Libro 35, octubre de 2016, página 2995. 


\section{CONCLUSIONES}

En el desarrollo del presente estudio, hemos advertido que el sistema de justicia para la defensa de derechos humanos en México es deficiente; en particular, por lo que se refiere a los medios de control constitucional, tanto en estructura como en hipótesis normativas ausentes y otras incluso prohibidas.

Hemos observado que si la votación de los ministros es de por lo menos ocho votos, invalidando disposiciones generales, se le dará efectos generales, lo cual sin duda es un error que lleva veintiséis años ahí porque la reforma data de 1994. En vez de velar por la naturaleza del acto, como es una ley y la finalidad del control constitucional, se le otorga efectos generales sin considerar su naturaleza, sino el número de ministros que vota ${ }^{123}$.

Como advertimos, en México solo existe el control a posteriori, ya que si bien es cierto que se permite a los particulares mediante el juicio de amparo antes de que tenga vigencia una norma, solo pueden impugnarse aquellas que están sancionadas y publicadas en el Diario Oficial de la Federación, es decir, aquellas cuya vigencia y consecuente violación son inminentes.

No existe obligación de que los ministros sepan derecho constitucional, interpretación constitucional, argumentación jurídica, lógica jurídica y neoconstitucionalismo ${ }^{124}$, ni de que los jueces, magistrados y ministros se actualicen en esas materias, situación que es preocupante por la inamovilidad del puesto del que gozan. Tampoco hay una implementación institucional integral de la reforma de la décima época ${ }^{125}$ que obligue a una visión neoconstitucional por todos los operadores de justicia, y así mismo, el procedimiento para elección de ministros dista mucho de la independencia buscada ${ }^{126}$.

123 Artículo 105, Fracción I, Inciso l), y artículo 42 de la Ley Reglamentaria de las Fracciones I y II del artículo 105 de la Constitución Política de los Estados Unidos Mexicanos.

124 A lo mucho, en los requisitos en el último párrafo del artículo 95 constitucional señala: "Los nombramientos de los Ministros deberán recaer preferentemente entre aquellas personas que hayan servido con eficiencia, capacidad y probidad en la impartición de justicia o que se hayan distinguido por su honorabilidad, competencia y antecedentes profesionales en el ejercicio de la actividad jurídica".

125 Acuerdo General número 9/2011, del Pleno de la Suprema Corte de Justicia de la Nación, por el que se determina el inicio de la décima época del Semanario Judicial de la Federación. Publicado en el Diario Oficial de la Federación el 12 de septiembre de 2011. Disponible en: http://www.dof.gob.mx/nota_detalle.php?codigo=5208843\&fecha=12/09/2011

126 El artículo 96 de la Constitución refiere que el presidente de la República mandará una terna al Senado, ante su rechazo mandará otra, ante su rechazó él elegirá quién debe ser ministro. 
Como vimos, ha quedado evidenciado que el único medio de defensa de derechos humanos que tiene el ciudadano en México, esto es, el juicio de amparo como medio de control constitucional, ha sido rebasado y se deben crear más figuras al margen de él con una estructura propia como la protección de los derechos difusos. La jurisprudencia, como señalamos, muchas veces en la práctica en vez de clarificar sobre la interpretación, complica el acceso a la justicia, amén de que no se puede impugnar y es obligatoria para los impartidores de justicia. No proceden en México la impugnación contra las resoluciones del Congreso, lo que ha permitido que las resoluciones más que apegarse a derecho puedan ser rencillas políticas no revisables.

Destaca la prohibición de impugnar reformas constitucionales anticonstitucionales, lo cual evidencia la falta de preparación para abordar estos temas por legisladores y todos los actores involucrados en la justicia, fundamentales en un Estado Constitucional. Se ha intentado cuidar en demasía la supuesta intromisión de un poder a otro, como en la omisión legislativa y en la acción de inconstitucionalidad y controversias constitucionales que solo invadirán competencias del Poder Ejecutivo y Legislativo si se llevan a cabo en Pleno y votan la mayoría de los ministros.

Existe confusión respecto al momento de impugnar normas de forma autoaplicativa y heteroaplicativa; tendría en dado caso que estar establecido en la misma norma incluso el supuesto de aplicación e impugnación, o mejor aún, establecer el control previo antes de la aprobación de la cámara revisora. Es necesario aclarar, establecer y ampliar los efectos de la suspensión en el juicio de amparo en la práctica para que el gobernado acuda con pleno conocimiento a tribunales u órganos no jurisdiccionales protectores de derechos humanos.

Los jueces tienen un gran mérito de haber resuelto hasta nuestros días con tantas deficiencias, por ejemplo, los problemas de medio ambiente, si el amparo era el único medio de protección y se requería interés jurídico para su procedencia. Qué figura se usaba entre particulares si no había ley hasta 2010, materia que contiene errores sustanciales porque se regula no por la naturaleza del acto sino por los actores, amén de los problemas de categorizar al particular como autoridad desde 2013.

Definitivamente, en México la reforma de 2011 se ostenta ante la comunidad jurídica como una innovación, cuando en realidad debe criticarse objetivamente sobre el atraso y temas pendientes en los operadores jurídicos. Tener un sistema de justicia donde las hipótesis de protección son insuficientes no puede aspirar a que los peticionarios de justicia la obtengan. El problema también estriba en que la reforma sustancial tendrá que admitir desde el mismo poder judicial sus áreas de mejora y áreas críticas, empezando por el perfil de los ministros y su método de elección, así como la creación de un órgano de control político independiente del Poder Judicial, 
pero que tenga independencia real de los demás poderes, integrado por conocedores de la materia de constitucional, neoconstitucionalismo, argumentación y lógica jurídica, pilar de la formación de un Estado Constitucional.

\section{REFERENCIAS}

Constitución Política de los Estados Unidos Mexicanos, Art. 40, 5 de febrero de 1917 (México), Disponible en: https://www.juridicas.unam.mx/legislacion/ordenamiento/constitucion-politica-de-los-estados-unidos-mexicanos

Enrique Díaz Bravo. ANÁLISIS Y REFLEXIONES SOBRE EL CONTROL DE CONSTITUCIONALIDAD DE LAS LEYES. REvISTA OPINIÓn JURÍDICA 30. Julio-diciembre 2016. Pág. 25-46. doi: https://doi.org/10.22395/ ojum.v15n30a1

EL UNIVERSAL. Diputados aprueban reforma para eliminar fuero al presidente. 29 de octubre de 2019. Disponible en: https://www.eluniversal.com.mx/nacion/politica/diputadosaprueban-reforma-para-eliminar-fuero-al-presidente

Erick Francisco Tapia Hernández y Alba Aurora Olvera Bustamante. La posición jurídica del Estado mexicano ante la jerarquía normativa de los tratados internacionales y la jurisprudencia de la Corte Interamericana de Derechos Humanos. Comisión Interamericana de Derechos Humanos (CIDH). 60 AÑOS DE LA COMIsión InTERAMERICANA de DeRECHOS Humanos. CIDH. (2020).

Erick Francisco Tapia Hernández. UnA PROPUESTA PARA REGULAR EL CONTROL CONSTITUCIONAL A PRIORI EN MÉXICO (NORMAS DE CARÁCTER GENERAL). Editado por el H. Congreso de la Unión. (2009). Pág. 132 y ss.

Erick Francisco Tapia Hernández. La necesidad de un Órgano de Control Político independiente del Poder Judicial de la Federación. Veredas, Revista del Pensamiento Sociológico 37. Juliodiciembre 2018. Disponible en: http://www.casadelibrosabiertos.uam.mx/contenido/contenido/Libroelectronico/veredas-37-web.pdf

Erick Francisco Tapia Hernández. La omisión de protección en diversas materias mediante acciones colectivas en el Estado mexicano. RevisTa Jurídica 6. Julio-diciembre 2018. Pág. 59 y ss. Disponible en: http://revistajuridica.uas.edu.mx/Revistajus6/REVISTA\%20JUS\%20VOLU MEN\%202\%20no.\%206.pdf 
Fabiola Martínez Ramírez. LAS CONTROVERSIAS CONSTITUCIONALES COMO MEDIO DE CONTROL CONSTITUCIOnAL. Editorial Universidad Nacional Autónoma de México. (s. f.). Disponible en: https:// archivos.juridicas.unam.mx/www/bjv/libros/6/2553/24.pdf

Francisco Fernández Segado. LA JUSTICIA CONSTITUCIONAL ANTE EL SIGLO XXI: LA PROGRESIVA CONVERGENCIA DE LOS SISTEMAS AMERICANO Y EUROPEO-KELSENIANO. Editorial Universidad Nacional Autónoma de México. (2004). Pág. 27.

Gustavo Zagrebelsky. El DERECHO dúctiL. 5. edición. Editorial Trotta. (2003). Pág. 110.

Héctor Fix Zamudio y Carmona Valencia. DeRECHO CONSTITUCIONAL, MEXICANO Y COMPARADO. 2. ${ }^{a}$ edición. Editorial Porrúa. (2001). Pág. 176.

Luciano Silva Ramírez. EL CONTROL JUDICIAL DE LA CONSTITUCIONALIDAD Y EL JUICIO DE AMPARO EN MÉXICO. Editorial Porrúa. (2008). Págs. 171-172.

Manuel Atienza. LAS RAZONES DEL DERECHO. TEORÍAS DE LA ARGUMENTACIÓn JURÍDICA. Editorial Universidad Nacional Autónoma de México. (2003). Pág. 26.

Margarita Beatriz Luna Ramos. Control constitucional sobre la Ley de Amparo. Coords. David Cienfuegos Salgado y Jesús Boanerges Guinto López. EL DERECHO MEXICANO CONTEMPORÁNEO RETOS Y DILEMAS. Editorial Universidad Autónoma de Chiapas. (2012). Pág. 359.

Mauro Cappelletti. LA JUSTICIA CONSTITUCIONAL (ESTUdios DE DERECHO COMPARADO). Editorial Universidad Nacional Autónoma de México. (1987). Pág. 201.

Miguel Covian Andrade. El CONTROL DE LA CONSTITUCIONALIDAD. FUndAMENTOS TEÓRICOS Y SISTEMAS DE CONTROL. Instituto de Investigaciones legislativas del Senado de la República. (2013). Disponible en: https://archivos.juridicas.unam.mx/www/bjv/libros/7/3180/9.pdf

Neldy San Martín. Senado rechaza eliminar fuero al presidente porque el dictamen no incluye a legisladores. Proceso. 3 de diciembre de 2019. Disponible en: https://www.proceso.com. mx/609330/senado-rechaza-eliminar-fuero-al-presidente-porque-el-dictamen-no-incluye-a-legisladores

Omar Granados. Jueces de Chihuahua piden asilo en EU. Animal Polítıco. 12 de enero de 2011. Disponible en: https://www.animalpolitico.com/2011/01/jueces-de-chihuahua-piden-asilo -en-eu-tras-inicio-de-juicio-politico/ 
Riccardo Guastini. ESTUdios SOBRE LA INTERPRETACIÓn CONSTITUCIONAL. 7. ${ }^{a}$ edición. Editorial Porrúa. (2006). Pág. 120.

Robert Alexy. Teoría de los derechos fundamentales. Centro de Estudios Constitucionales. (1993). Pág. 526.

Rodolfo Vigo. LA INTERPRETACIÓn (ARgumentACIÓN) JURídicA EN EL ESTAdo de DERECHO Constitucional. Editorial Tirant lo Blanch. (2017). Pág. 70.

Sergio López-Ayllón y Florencio Valladares. Las acciones de inconstitucionalidad en la Constitución mexicana: balance empírico de doce años de ejercicio. REVISTA CUESTIONES Constitucionales 21. Julio-diciembre 2009. Pág. 183. doi: http://dx.doi.org/10.22201/ iij.24484881e.2009.21.5883. Disponible en: https://revistas.juridicas.unam.mx/index.php/ cuestiones-constitucionales/article/view/5883

Silvia Arellano. Senado aprueba reforma para quitar fuero a Presidente y legisladores. MILENIO. 26 de noviembre de 2020. Disponible en: https://www.milenio.com/politica/ senado-aprueba-reforma-eliminar-fuero-presidente

Suprema Corte de Justicia de la Nación. ¿QUÉ SON LAS ACCIONES DE INCONSTITUCIONALIDAD? 2. a edición. Editorial Suprema Corte de Justicia de la Nación. (2004). Pág. 43. Disponible en: https:// www.scjn.gob.mx/sites/default/files/publicaciones_scjn/publicacion/2016-10/51297_pd_0. pdf 